\title{
Cáncer de riñón presentando trombo de la vena cava hasta la aurícula derecha. Imágenes de RMN
}

\author{
J. Cabral Ribeiro, C. Braz Silva, M. Cerqueira Alves, A. Lemos Sousa, A. Ribeiro Santos.
}

Servicio de Urología. Hospital de São Marcos. Braga, Portugal.

Actas Urol Esp 2005; 29 (3): 337

$\mathrm{H}$ ombre de 71 años de edad con razonable estado general y con antecedentes de tabaquismo severo desde los 20 años e hipertensión. Se presentó a su cardióloga por sintomatología no específica de mal estar general siendo detectado por eco cardiografía una masa en la aurícula derecha. Se programó estudio complementario pero fue admitido al día siguiente en Urología por hematuria total.

La investigación detectó un cáncer afectando la extremidad superior del riñón izquierdo de 4 cm de mayor dimensión con trombo asociado de la vena renal izquierda que se extendía a través de la vena cava inferior dos centímetros distal a la vena renal y próximamente hasta la aurícula derecha del corazón (imágenes).

El estudio realizado no detectó enfermedad metastásica (TAC cerebral, gammagrafía ósea, TAC y RMN toracoabdominal) y los parámetros analíticos se presentaban dentro de los valores normales por lo que se referenció al paciente a una unidad conjunta para cirugía urológica y cardiotorácica.

Dr. J. Cabral Ribeiro

Servicio de Urología

Apartado 2242

4701- 296 Braga (Portugal)
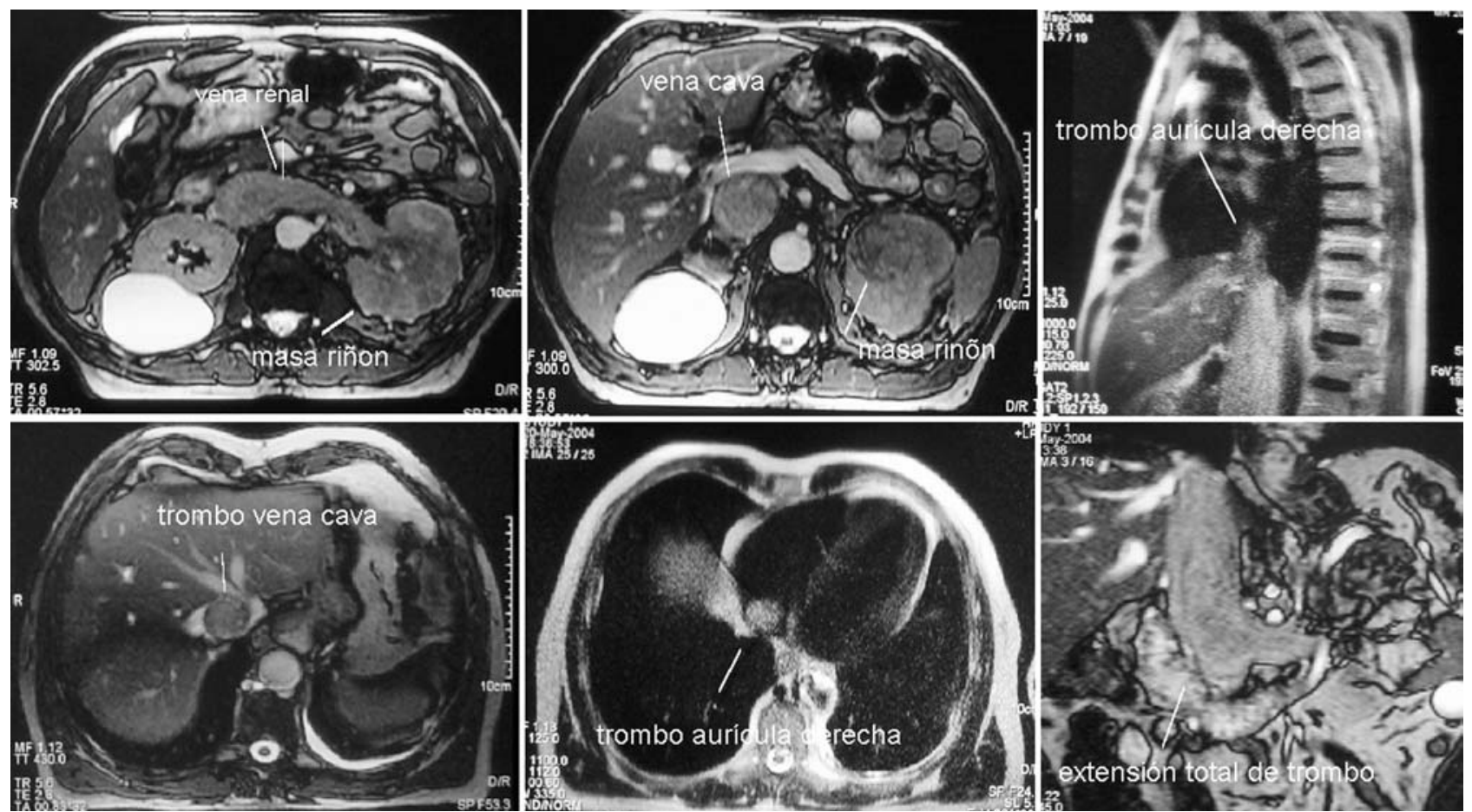